JIEB (ISSN : 2442-4560) available online at : ejournal.stiepancasetia.ac.id

\title{
KINERJA STAF DAN EFEKTIVITAS KERJA APARAT PEMERINTAH DESA KRAMAT JEGU KECAMATAN TAMAN KABUPATEN SIDOARJO TERHADAP KEPUASAN MASYARAKAT
}

\author{
Diah Ayu Sanggarwati ${ }^{1}$, Rifda Fitrianty ${ }^{1}$ dan Suryaningtyas ${ }^{2}$ \\ ${ }^{1}$ Sekolah Tinggi Ilmu Ekonomi Mahardhika \\ Jl. Wisata Menanggal No. 42 A, Surabaya, Jawa Timur \\ e-mail:dayu.dtricova@gmail.com \\ ${ }^{2}$ Sekolah Menengah Kejuruan Negeri 4 Surabaya \\ Jl. Kranggan, No.81-101, Sawahan, Surabaya \\ e-mail: suryaningtyaskuswandi@gmail.com
}

\begin{abstract}
This study aims to analyze the influence of staff performance, and effectiveness to the satisfaction of rural communities in Kramat Jegu village Taman District, Sidoarjo Regency. This study is a non-experimental study conducted using questionnaires in Kramat Jegu village Taman District, Sidoarjo Regency, with the 390 respondents as research's samples. The analysis used in this study is the regression analysis. Based on the results of the analysis, it can be seen that staff performance, and effectiveness simultaneously and partially have positive effect on people's satisfaction in Kramat Jegu Sidoarjo. Findings of this research shows that Kramat Jegu village Taman District, Sidoarjo Regency officials must always keep up their good performance and effectiveness to create a satisfactory service to the villagers.
\end{abstract}

Keywords: performance, work effectiveness, community satisfaction

\begin{abstract}
Abstrak: Penelitian ini bertujuan untuk menganalisis pengaruh kinerja staf dan efektivitas kerja terhadap kepuasan masyarakat Desa Kramat Jegu Kecamatan Taman Kabupaten Sidoarjo. Penelitian ini merupakan penelitian non eksperimen yang dilakukan dengan menggunakan kuisioner di Desa Kramat Jegu Kecamatan Taman Kabupaten Sidoarjo, dengan 390 responden sebagai sampel penelitian. Analisis yang digunakan dalam penelitian ini adalah analisis regresi. Berdasarkan hasil analisis dapat diketahui bahwa kinerja staf dan efektivitas kerja secara simultan maupun parsial berpengaruh positif terhadap kepuasan masyarakat di Desa Kramat Jegu Kecamatan Taman Kabupaten Sidoarjo. Temuan penelitian ini menunjukkan bahwa pemerintah Desa Kramat Jegu Kecamatan Taman Kabupaten Sidoarjo harus terus mempertahankan kinerja dan efektivitas dari aparatnya untuk menciptakan pelayanan terhadap masyarakat desa yang memuaskan.
\end{abstract}

Kata kunci: kinerja, efektivitas kerja, kepuasan masyarakat

\section{Latar Belakang}

Dewasa ini pada pemerintahan

Presiden Joko Widodo, peran pelayanan menjadi prioritas utama. Karena dengan perhatian tersebut diharapkan dampak kepercayaan dari masyarakat kepada pemerintah akan bisa dipulihkan. Kepuasan merupakan tingkat perasaan setelah membandingkan kinerja atau hasil dengan harapannya. Jadi tingkat kepuasan adalah fungsi dari perbedaan antara kinerja yang dirasakan dengan harapannya (Oliver dalam Suprapto, 2001:233). Pengukuran kepuasan masyarakat merupakan elemen penting dalam menyediakan pelayanan yang baik, antara lain dari segi biaya, waktu, prosedur dan jarak dengan pusat pelayanan. 
Untuk mengukur kepuasan masyarakat digunakan indikator antara lain sesuai dengan harapan, layanan selama proses menikmati jasa, suasana dan kondisi fisik lingkungan yang menyenangkan. Apabila masyarakat merasa tidak puas terhadap suatu pelayanan yang disediakan, maka pelayanan tersebut dapat dipastikan in efektif dan in efisien. Dalam kondisi era sekarang ini sangat penting bagi pelayanan publik, untuk menumbuhkan kepuasan maupun kepercayaan terhadap kebijakan yang digulirkan, dengan tujuan untuk memperbaiki tingkat pelayanan yang sudah ada dalam semua bidang.

Prinsip dasar kepuasan masyarakat atau publik tergantung pada persepsi dan harapan masyarakat untuk mendapatkan pelayanan yang baik atau pelayanan prima. Beberapa teori menyatakan sulit mengukur kepuasan seperti yang diharapkan oleh masyarakat atau publik. Suatu lembaga yang melayani masyarakat perlu mengetahui beberapa faktor yang mempengaruhi persepsi dan harapan masyarakat dalam rangka meningkatkan kepuasan masyarakat. Kepuasan masyarakat atau publik sangat tergantung pada kualitas implementasi yang diberikan oleh lembaga tersebut, dalam hal ini pemerintahan Desa Kramat Jegu Kecamatan Taman Kabupaten Sidoarjo. Kualitas dalam penyelenggaraan pelayanan, dewasa ini merupakan tuntutan yang sangat normatif. Masyarakat pada umumnya tidak dapat lagi dipenuhi kebutuhannya hanya atas dasar standar pemerintah semata, melainkan juga menuntut adanya kualitas pelayanan yang ditentukan oleh kebutuhan masyarakat itu sendiri. Kebutuhan tersebut ditujukan baik terhadap barang pribadi maupun terhadap barang publik (Lean, Iain Mc, 1999).

Berbagai pengertian tentang pelayanan telah diungkapkan oleh para ahli, namun pada dasarnya pelayanan merupakan aktivitas atau manfaat yang ditawarkan oleh organisasi atau perorangan kepada konsumen (customer) yang bersifat tidak berwujud dan tidak dapat dimiliki (Daviddow dan Uttal, 1989). Sementara yang disebut dengan konsumen atau customer adalah masyarakat yang mendapat manfaat dari aktivitas yang dilakukan oleh organisasi atau petugas.

Pelayanan yang dilakukan oleh pemerintah sering disebut dengan pelayanan umum. Yang dimaksud dengan pelayanan umum adalah sesuatu yang disediakan, baik oleh organisasi pemerintah maupun swasta. Karena masyarakat umumnya tidak dapat memenuhi sendiri kebutuhannya kecuali secara kolektif. Pemenuhan kebutuhan dilakukan untuk seluruh masyarakat guna kesejahteraan sosial (Londsdale: 1994). Sementara pengertian pelayanan umum sesuai Keputusan MenPAN nomor 81 tahun 1993 adalah segala bentuk pelayanan umum yang dilaksanakan oleh instansi pemerintah di pusat, di daerah, dan di lingkungan Badan Usaha Milik Negara. Sedangkan pelayanan publik adalah pelayanan prima atau pelayanan yang dapat memenuhi harapan masyarakat atau sesuai dengan standar dan asas-asas pelayanan publik atau masyarakat. Dalam organisasi publik hal ini sebenarnya telah menjadi tuntutan, sejak munculnya teori negara baru (Frederickson) tentang azas keadilan. Oleh sebab itu dalam pelayanan prima juga perlu adanya standar pelayanan sebagai ukuran yang telah ditentukan untuk pembakuan pelayanan yang baik, berkualitas dan berkeadilan.

Pelayanan prima adalah suatu pelayanan yang terbaik dalam memenuhi kebutuhan dan harapan pelanggan atau pelayanan yang memenuhi standar kualitas karena dituntut sesuai dengan harapan dan kepuasan masyarakat (Maddy, 2009:86).

Berdasarkan SK Men PAN dan Reformasi Birokrasi Nomor 15 Tahun 2014, tentang pedoman standar pelayanan. Salah satu pasal 1(ayat1) mengatakan bahwa setiap penyelenggara pelayanan publik wajib menetapkan dan menerapkan standar pelayanan publik untuk setiap jenis pelayanan. Pelaksanaan tugas dan kegiatan penyelenggaraan pelayanan publik, sejak dari proses kebijakan, perencanaan, pelaksanaan dan pengawasan atau pengendalian. Prosedur pelayanan publik yang sederhana, tidak berbelit-belit, mudah dipahami, dan mudah dilaksanakan, serta diwujudkan dalam bentuk bagan alur (flow chart) yang dipampang dalam ruangan pelayanan. Prosedur 
pelayanan adalah rangkaian proses atau tata kerja yang berkaitan satu dengan lainnya, sehingga menunjukkan adanya tahapan secara jelas dan pasti serta cara-cara yang harus ditempuh dalam rangka penyelesaian sesuatu pelayanan.

Dalam otonomi daerah kemudian diperkuat dengan UU RI No.6 tahun 2014 yang mengatur tentang Desa dalam penjelasannya merupakan kesatuan masyarakat hukum yang memiliki batas wilayah yang berwenangan untuk mengatur dan mengurus urusan pemerintahan, kepentingan masyarakat setempat berdasarkan prakarsa masyarakat, hak asalusul dan adat istiadat setempat yang diakui dan dihormati dalam sistem pemerintahan Negara kesatuan RI. Meski sudah diatur dalam bentuk undang-undang, keputusan menteri pendayagunaan aparat Negara dan reformasi birokrasi, pergub, perbup, perwali meski dengan memanfaatkan IT, realita dilapangan masih belum mampu menjawab apa yang seharusnya diharapkan masyarakat itu sendiri seperti transparansi, prosedur, biaya, waktu serta performance pelaksana yang kurang akomodatif.

Kinerja merupakan prestasi kerja atau performance yaitu hasil kerja selama periode tertentu dibanding dengan berbagai kemungkinan. Menurut Simamora (2003:45) kinerja merupakan keberhasilan organisasi dalam mencapai misinya. Kepala Desa sebagai aparatur pemerintahan Desa khususnya yang ada di Desa Kramat Jegu Kecamatan Taman Kabupaten Sidoarjo tentu dipengaruhi oleh kebutuhan seperti yang dimaksud di atas, dan mereka bekerja keras sehingga dapat memenuhi kebutuhan tersebut. Disamping faktor komitmen juga faktor pengalaman kerja sebagai kepala Desa juga mempengaruhi prestasi kerja (kinerja) dalam melaksanakan tugas di pemerintahan Desa.

Manajemen kinerja merupakan salah satu bentuk strategi yang bersifat menyeluruh dan menjamah semua elemen, unsur atau input yang harus didayagunakan oleh organisasi dan manajemen untuk meningkatkan kinerja organisasi (Stephen, P. Robin.1996). Dengan kata lain, manajemen kinerja berhubungan dengan perencanaan strategis, anggaran pelaksanaan kebijakan desentralisasi dan otonomi daerah sesuai dengan UU RI No. 23 Tahun 2014 telah membawa harapan baru bagi penyelenggaraan kepemerintahan daerah, khususnya setelah bergulirnya era reformasi dan dilaksanakannya UU No.23 Tahun 2014 tentang Pemerintahan Daerah.

Kepala Desa merupakan pimpinan penyelenggaraan pemerintahan Desa berdasarkan kebijakan yang ditetapkan bersama Badan Permusyawaratan Desa (BPD). Kepala Desa juga memiliki wewenang menetapkan Peraturan Desa yang telah mendapat persetujuan bersama BPD. Kepala Desa dipilih langsung melalui Pemilihan Kepala Desa (Pilkades) oleh penduduk Desa setempat. Untuk memperoleh pelayanan, masyarakat diwajibkan memenuhi persyaratan yang telah ditetapkan oleh pemberi pelayanan, baik berupa persyaratan teknis dan atau persyaratan administratif sesuai dengan ketentuan peraturan perundang-undangan.

Kepala pusat pendidikan SPIMNAS bidang kepemimpinan LAN menyatakan harapannya agar kementerian PAN menata kembali sistem birokrasi di Indonesia karena data yang ada di kepala pusat pendidikan menunjukkan bahwa jumlah PNS sekitar 4 juta saat ini $53 \%$ perlu dibina kembali agar tingkat kualitas pelayanan bisa di implementasikan sesuai harapan masyarakat atau publik.

Berdasarkan latar belakang di atas, maka rumusan masalah dari penelitian ini adalah sebagai berikut:

1. Apakah kinerja staf berpengaruh signifikan terhadap kepuasan masyarakat di Desa Kramat Jegu Kecamatan Taman Kabupaten Sidoarjo?

2. Apakah efektivitas kerja berpengaruh signifikan terhadap kepuasan masyarakat di Desa Kramat Jegu Kecamatan Taman Kabupaten Sidoarjo?

3. Apakah kinerja staf, dan efektivitas kerja secara simultan berpengaruh signifikan terhadap kepuasan masyarakat Desa Kramat Jegu Kecamatan Taman Kabupaten Sidoarjo?

\section{Kajian Literatur}


Performance atau kinerja merupakan hasil atau keluaran dari suatu proses (Nurlaila, 2010:71). Menurut pendekatan perilaku dalam manajemen, kinerja adalah kuantitas atau kualitas sesuatu yang dihasilkan atau jasa yang diberikan oleh seseorang yang melakukan pekerjaan (Luthans, 2005:165). Kinerja merupakan prestasi kerja, yaitu perbandingan antara hasil kerja dengan standar yang ditetapkan (Dessler, 2000:41). Kinerja adalah hasil kerja baik secara kualitas maupun kuantitas yang dicapai oleh seseorang dalam melaksanakan tugas sesuai tanggung jawab yang diberikan (Mangkunegara, 2002:22). Kinerja adalah hasil atau tingkat keberhasilan seseorang secara keseluruhan selama periode tertentu dalam melaksanakan tugas dibandingkan dengan berbagai kemungkinan, seperti standar hasil kerja, target atau sasaran atau kriteria yang telah ditentukan terlebih dahulu telah disepakati bersama (Rivai dan Basri, 2005:50). Sedangkan Mathis dan Jackson (2006:65) menyatakan bahwa kinerja pada dasarnya adalah apa yang dilakukan atau tidak dilakukan oleh pegawai. Manajemen kinerja adalah keseluruhan kegiatan yang dilakukan untuk meningkatkan kinerja perusahaan atau organisasi, termasuk kinerja masing-masing individu dan kelompok kerja di perusahaan tersebut.

Karakteristik orang yang mempunyai kinerja tinggi adalah sebagai berikut (Mangkunegara, 2002:68):

1. Memiliki tanggung jawab pribadi yang tinggi.

2. Berani mengambil dan menanggung resiko yang dihadapi.

3. Memiliki tujuan yang realistis.

4. Memiliki rencana kerja yang menyeluruh dan berjuang untuk merealisasi tujuannya.

5. Memanfaatkan umpan balik (feedback) yang konkrit dalam seluruh kegiatan kerja yang dilakukannya.

6. Mencari kesempatan untuk merealisasikan rencana yang telah diprogramkan.

Indikator untuk mengukur kinerja karyawan secara individu ada enam indikator, yaitu (Robbins, 2006:260):

1. Kualitas. Kualitas kerja diukur dari persepsi karyawan terhadap kualitas pekerjaan yang dihasilkan serta kesempurnaan tugas terhadap keterampilan dan kemampuan karyawan.

2. Kuantitas. Merupakan jumlah yang dihasilkan dinyatakan dalam istilah seperti jumlah unit, jumlah siklus aktivitas yang diselesaikan.

3. Ketepatan waktu. Merupakan tingkat aktivitas diselesaikan pada awal waktu yang dinyatakan, dilihat dari sudut koordinasi dengan hasil output serta memaksimalkan waktu yang tersedia untuk aktivitas lain.

4. Efektivitas. Merupakan tingkat penggunaan sumber daya organisasi (tenaga, uang, teknologi, bahan baku) dimaksimalkan dengan maksud menaikkan hasil dari setiap unit dalam penggunaan sumber daya.

5. Kemandirian. Merupakan tingkat seorang karyawan yang nantinya dapat menjalankan fungsi kerjanya.

6. Komitmen kerja. Merupakan suatu tingkat dimana karyawan mempunyai komitmen kerja dengan instansi dan tanggung jawab karyawan terhadap kantor.

Pada hahekatnya, kinerja personel yang tinggi sangat diharapkan oleh sebuah organisasi. Hal itu, karena berdampak positif pada kinerja institusional. Maka harus dipahami, kesuksesan suatu organisasi sangat tergantung pada kinerja sumber daya manusianya (Sherman \& George, 2007). Menurut Irawan (2007), kinerja adalah hasil kerja yang dapat diamati dan dapat diukur. Sementara itu Smith (2002) menyatakan bahwa kinerja adalah "output drived from processed, human or otherwise". Selain itu kinerja merupakan gambaran keseluruhan dari sebuah entitas organisasi.

Berdasarkan pengertian di atas, dapat diketahui adanya unsur-unsur penting dalam kinerja, yakni hasil kerja, manusia (pegawai), proses atau organisasi, terbukti secara konkrit dapat diamati dan dapat diukur. Dari unsurunsur tersebut diperlukan pembahasan secara kompleks berkaitan dengan terbukti secara kualitas, kuantitas dan dapat diukur. Hal ini disebabkan landasan teoritis yang berkaitan dengan hasil kerja, pegawai, proses atau organisasi pada umumnya yang dapat 
diimplementasikan pada berbagai organisasi secara universal. Sedangkan bukti pekerjaan secara kuantitas dapat diukur dengan landasan teoritis yang spesifik, serta dapat diterapkan secara universal. Bukti kongkrit pekerjaan yang dapat diukur antar organisasi satu dengan yang lainnya berbeda-beda, sehingga untuk melakukan pengukuran kinerja terlebih dahulu dirumuskan standar pengukuran kinerja yang mempengaruhi, antara lain: jenis pekerjaan, struktur organisasi, iklim organisasi, program kerja, dan sebagainya yang tentunya berbeda-beda pula antara satu dengan lainnya.

Begitu pentingnya masalah kinerja pegawai ini, sehingga tidak salah bila inti pengelolaan sumber daya manusia merupakan modal yang perlu dikelola. Bagaimana mengelola kinerja SDM yang mengarah pada the right man on the right place. Mengelola manusia dalam konteks organisasi berarti mengelola manusia agar dapat menghasilkan kinerja yang maksimal bagi organisasi. Oleh karenanya kinerja pegawai perlu dikelola secara baik untuk mencapai tujuan organisasi, sehingga menjadi suatu konsep manajemen kinerja (performance management). Menurut definisi tersebut, manajemen kinerja adalah suatu proses strategis dan terpadu guna menunjang keberhasilan organisasi melalui pengembangan performansi SDM. Dalam manajemen kinerja kemampuan SDM sebagai kontributor individu dan bagian dari kelompok yang dikembangkan melalui proses bersama antara manajer dan individu yang lebih berdasarkan kesepakatan daripada tupoksi. Kesepakatan ini meliputi tujuan (objectives), persyaratan pengetahuan, keterampilan dan kemampuan. Manajemen kinerja juga dapat menggalang partisipasi aktif setiap anggota organisasi untuk mencapai sasaran organisasi melalui penjabaran sasaran individu maupun kelompok sekaligus mengembangkan protensinya agar dapat mencapai sasarannya itu. Berdasarkan tugasnya ini, manajemen kinerja dapat dijadikan landasan bagi promosi, mutasi dan evaluasi, sekaligus penentuan kompensasi dan penyusunan program pelatihan. Manajemen kinerja juga dapat dijadikan umpan balik untuk pengembangan karier dan pengembangan pribadi SDM.

Keunggulan manajemen kinerja adalah penentuan sasaran yang jelas dan terarah. Di dalamnya terdapat dukungan, bimbingan, dan umpan balik agar tercipta peluang terbaik untuk meraih sasaran yang menyertai peningkatan komunikasi antara atasan dan bawahan, karena pada dasarnya manajemen kinerja merupakan proses komunikasi berkelanjutan antara atasan dan bawahan dengan tujuan memperjelas dan menyepakati hal-hal:

1. Fungsi pokok pekerjaan bawahan.

2. Bagaimana pekerjaan bawahan berkontribusi pada pencapaian tujuan organisasi.

3. Pengertian "efektif" dan "berhasil" dalam pelaksanaan pekerjaan bawahan.

4. Bagaimana bawahan dapat bekerja sama dengan atasan dalam rangka efektivitas pelaksanaan pekerjaan bawahan.

5. Bagaimana mengukur efektivitas (baca: kinerja) pelaksanaan pekerjaan bawahan.

6. Berbagai hambatan efektivitas dan alternatif untuk menyingkirkan hambatanhambatan tersebut.

7. Michael Porter, profesor dari Harvard Business of School menyatakan bahwa kita tidak bisa memanajemeni sesuatu yang tidak dapat kita ukur. Pertama, organisasi yang tidak memiliki indikator kinerja biasanya tidak bisa diharapkan untuk mampu mencapai kinerja yang memuaskan bagi pihak yang berkepentingan (stakeholders). Kedua, ukuran kinerja tersebut biasanya dituangkan dalam suatu bentuk kesepakatan antara atasan dan bawahan yang sering disebut sebagai suatu kontrak kinerja (performance contract).

Konsep yang sangat terkenal adalah penilaian 360 derajat, di mana penilaian kinerja dilakukan oleh atasan, bawahan, rekan sekerja, dan pengguna jasa, karena pada prinsipnya manusia itu berpikir secara subyektif, namun dengan berpikir bersama mampu untuk mengubah sikap subyektif itu menjadi mendekati obyektif, atau berpikir 
bersama jauh lebih obyektif daripada berpikir sendiri-sendiri.

Menurut Siagian (2008) menyatakan bahwa ada tiga faktor yang dapat mempengaruhi kinerja seseorang, yaitu: 1) faktor motivasi, 2) faktor kemampuan, dan 3) faktor ketepatan penugasan. Keberhasilan yang dicapai oleh organisasi menunjukkan tingkat kinerja organisasi yang semakin baik. Upaya yang dilakukan oleh para ahli organisasi agar dapat mendiagnosa dengan tepat adalah dengan menggunakan beberapa teori. Salah satu teori yang paling banyak digunakan adalah teori Weisbord, kelebihan dari teori ini adalah kemampuan dalam memahami dan memvisualisasikan kenyataan.

Weisbord (2008) melukiskan teorinya sebagai layar radar yang didalamnya terkandung pijaran yang mampu menangkap suatu gejala tentang masalah atau isu baik dan buruk. Teori ini menemukan adanya model enam kotak (six box models) yang menjadi fokus bahasan yaitu : (1) kepemimpinan; (2) komunikasi; (3) kompensasi; (4) tujuan; (5) struktur; (6) mekanisme tata kerja. Menurut teori ini yang penting adalah menemukan kesenjangan antar dimensi formal suatu oganisasi dengan property informalnya. Semakin besar jurang kesenjangan, ini berarti akan semakin besar pula kemungkinan kegagalan organisasi dalam menjalankan tugasnya.

Penilaian kinerja adalah proses yang dilakukan oleh organisasi untuk menilai kinerja (job performance). Penilaian kinerja pegawai merupakan keseluruhan proses penilaian yang berkenaan dengan sejauh mana seseorang melakukan tugas yang dibebankan kepadanya. Dalam melakukan penilaian kinerja, pertama yang harus dilakukan adalah melakukan identifikasi aspek-aspek atau dimensi kinerja yang dapat menentukan kinerja yang efektif (efective job performance).

Menurut Irawan, tujuan pekerjaan harus bersifat ideal, tetapi sekaligus realistis. Ideal berarti tujuan tersebut dapat tercapai seluruhnya dan hanya jika segala persyaratan yang dituntut tersedia dengan mudah. Realistis berarti tujuan tersebut diformulasikan dengan mempertimbangkan hal-hal relevan dan faktor-faktor yang mempengaruhinya (Irawan, 2007). Dalam upaya mencapai tujuan tersebut, diperlukan manajemen kinerja atau sistem yang melibatkan sejumlah proses yang didesain untuk mengelola performance karyawan, termasuk sejumlah komponen di antaranya desain pekerjaan, struktur penggajian, proses seleksi, pelatihan dan induksi, serta penilaian bagaimana karyawan melakukan pekerjaannya dan kebijakan pemberian imbalan serta pengembangan performance. Dengan demikian penilaian kinerja rnerupakan bagian dari performance management (Kramar, Mc Graw, Schuler, 2007).

Berkaitan dengan kebutuhan tersebut, Dessler (2000) mengemukakan bahwa proses penilaian kinerja meliputi: 1) Menetapkan standar pekerjaan; 2) Menilai kinerja nyata relatif para karyawan; 3) Menyediakan feedback kepada karyawan dengan tujuan memotivasi seseorang untuk mengurangi rendahnya performance atau melanjutkan usaha peningkatan performance. Hal-hal yang berkaitan dengan penilaian kinerja di samping perlunya standar kinerja, diperlukan pula ruang lingkup kinerja yang dinilai. Mitchell (2008) memberikan sejumlah ruang lingkup aspek-aspek yang perlu dinilai dalam menilai kinerja seseorang, yaitu kualitas kerja, ketepatan waktu, inisiatif, kapabilitas, dan komunikasi.

Efektivitas kerja merupakan suatu keadaan tercapainya tujuan yang diharapkan atau dikehendaki melalui penyelesaian pekerjaan sesuai dengan rencana atau waktu yang telah ditentukan. Adapun pengertian efektivitas menurut para ahli diantaranya sebagai berikut, menurut Siagian (2007:24) efektivitas adalah pemanfaatan sumber daya, sarana dan prasarana dalam jumlah tertentu yang secara sadar ditetapkan sebelumnya untuk menghasilkan sejumlah barang atas jasa kegiatan yang dijalankan. Efektivitas menunjukkan keberhasilan dari segi tercapai tidaknya sasaran yang telah ditetapkan. Jika hasil kegiatan semakin mendekati sasaran berarti makin tinggi efektivitasnya.

Pada prinsipnya efektivitas individu para anggotanya didalam melaksanakan tugas sesuai dengan kedudukan dan peran 
mereka masing-masing dalam organisasi tersebut. Sehubungan dengan hal tersebut para ahli mengemukakan definisi tentang efektivitas sebagai berikut, menurut Umar (2003:121) efektivitas merupakan harapan yang memberikan gambaran seberapa jauh target dapat dicapai. Sedangkan menurut Hadyaningrat (1989:38) efektivitas adalah kemampuan seseorang atau sekelompok orang yang sedang melaksanakan aktivitas untuk mendapatkan atau melahirkan hasil dari kegiatan itu. Disamping itu Schermerhon (1998:5), mengatakan bahwa efektivitas kerja merupakan suatu ukuran tentang pencapaian suatu tugas dan tujuan.

Dari pendapat para ahli diatas, dapat disimpulkan bahwa suatu pekerjaan dapat dilaksanakan secara tepat sasaran, efektif, dan efisien apabila pekerjaan tersebut dilaksanakan dengan benar sesuai dengan yang telah direncanakan, maka jelas bahwa sesungguhnya efektivitas kerja tidak lain adalah individu-individu atau beberapa kelompok atau bagian terutama pegawai dalam satu unit organisasi atau perusahaan untuk dapat melaksanakan tujuan yang dicapai dalam suatu sistem yang ditentukan dengan suatu pandangan untuk memenuhi kebutuhan sistem itu sendiri.

Ada empat faktor yang mempengaruhi efektivitas kerja, seperti yang dikemukakan oleh Richard M. Steers (1980:9), yaitu:

1. Karakteristik Organisasi.

Karakteristik organisasi terdiri dari struktur dan teknologi organisasi yang dapat mempengaruhi segi-segi tertentu dari efektivitas dengan berbagai cara. Yang dimaksud struktur adalah hubungan yang relatif tepat sifatnya, seperti dijumpai dalam organisasi, sehubungan dengan susunan sumber daya manusia, struktur meliputi bagaimana cara organisasi menyusun orang-orangnya dalam menyelesaikan pekerjaan, sedangkan yang dimaksud teknologi adalah mekanisme suatu organisasi umtuk mengubah masukan mentah menjadi keluaran.

2. Karakteristik Lingkungan.

Lingkungan luar dan lingkungan dalam juga telah dinyatakan berpengaruh atas efektivitas, keberhasilan hubungan organisasi lingkungan tampaknya amat tergantung pada tingkat variabel kunci yaitu tingkat keterdugaan keadaan lingkungan, ketepatan persepsi atas keadaan lingkungan, tingkat rasionalisme organisasi. Ketiga faktor ini mempengaruhi ketepatan tanggapan organisasi terhadap perubahan lingkungan.

3. Karakteristik Pekerja.

Pada kenyataannya para anggota organisasi merupakan faktor pengaruh yang paling penting karena perilaku merekalah yang dalam jangka panjang akan memperlancar atau merintangi tercapainya tujuan organisasi. Pekerja merupakan sumber daya yang langsung berhubungan dengan pengelolaan semua sumber daya yang ada di dalam organisasi, oleh sebab itu perilaku pekerja sangat berpengaruh terhadap pencapaian tujuan organisasi.

4. Karakteristik Kebijaksanaan dan Praktek Manajamen.

Dengan makin rumitnya proses teknologi dan perkembangan lingkungan maka peranan manajemen dalam mengkoordinasi orang dan proses demi keberhasilan organisasi menjadi semakin sulit.

Alat ukur efektivitas kerja, menurut Richard dan M. Steers (1980:192) meliputi unsur kemampuan menyesuaikan diri atau prestasi kerja dan kepuasan kerja:

1. Kemampuan menyesuaikan diri

Kemampuan manusia terbatas dalam segala hal, sehingga dengan keterbatasannya menyebabkan manusia tidak dapat mencapai pemenuhan kebutuhannya tanpa melalui kerjasama dengan orang lain. Hal ini sesuai pendapat Richard M. Steers, yang menyatakan bahwa kunci keberhasilan organisasi adalah kerjasama dalam pencapaian tujuan jika kemampuan menyesuaikan diri tersebut dapat berjalan, maka tujuan organisasi dapat tercapai. 
2. Prestasi kerja

Prestasi kerja adalah suatu hasil kerja yang dicapai seseorang dalam melaksanakan tugas-tugas yang dibebankan kepadanya yang didasarkan atas kecakapan, pengalaman, kesungguhan dan waktu (Hasibuan, 2001:94). Dari pendapat tersebut dapat disimpulkan bahwa dengan kecakapan, pengalaman, kesungguhan waktu yang dimiliki oleh pegawai, maka tugas yang diberikan, dapat dilaksanakan sesuai dengan tanggung jawab yang dibebankan kepadanya.

Kepuasan konsumen atau masyarakat adalah perasaan senang atau kecewa seseorang yang muncul setelah membandingkan kinerja produk yang dipikirkan terhadap kinerja yang diharapkan. Kotler menyatakan bahwa kepuasan pelanggan adalah tingkat perasaan seseorang setelah membandingkan kinerja atau hasil yang ia rasakan dibandingkan dengan harapannya (Kotler, Philip dan Kevin Lane Keller, 2007). Sedangkan Wilkie mendefinisikan kepuasan pelanggan sebagai suatu tanggapan emosional pada evaluasi terhadap pengalaman konsumsi suatu produk atau jasa. Tingkat kepuasan masyarakat terhadap pelayanan merupakan faktor yang penting dalam mengembangkan suatu sistem penyediaan pelayanan yang tanggap terhadap keluhan maupun kebutuhan masyarakat, efisiensi biaya serta efektifitas waktu, prosedur sederhana dan mudah dipersepsikan atau dipahami masyarakat luas.

Menurut Hamdani, A. 2006, empat cara untuk meningkatkan kepuasan masyarakat antara lain:

1. Memberikan kualitas layanan yang baik dan prima.

2. Menjalin komunikasi yang baik dengan masyarakat.

3. Empati, sikap empati kepada masyarakat membantu memahami apa yang dibutuhkan oleh masyarakat, sehingga membantu kita untuk memberikan layanan yang membuat masyarakat puas.

4. Selalu dalam kejujuran, kejujuran adalah kunci dalam memberikan kepercayaan masyarakat.
5. Ada beberapa faktor yang dapat dipertimbangkan oleh masyarakat dalam menilai suatu pelayanan, yaitu: ketepatan waktu, dapat dipercaya, kemampuan teknis, diharapkan, berkualitas dan biaya yang sesuai. Berdasarkan faktor-faktor tersebut, masyarakat sendiri yang menilai tingkat kepuasan yang mereka terima dari barang atau jasa spesifik yang diberikan, serta tingkat kepercayaan mereka terhadap kemampuan pemberi pelayanan. (Atmaja, H.S. 2003).

Tuntutan kualitas dalam penyelenggaraan pelayanan dewasa ini dirasakan sangat meningkat. Masyarakat pada umumnya tidak dapat lagi dipenuhi kebutuhannya atas dasar standar pemerintah semata, melainkan telah dituntut adanya kualitas layanan yang ditentukan oleh kebutuhan masyarakat sendiri. Kebutuhan tersebut ditujukan baik terhadap barang privat (private goods) maupun terhadap barang publik (public goods).

Barang layanan privat dapat dipenuhi melalui mekanisme pasar, sementara barang publik tidak dapat dipenuhi melalui mekanisme pasar melainkan harus melalui pengaturan atau kebijakan yang dilakukan oleh pemerintah (Lean, Iain Mc., 1989:19). Penyelenggaraan pelayanan dipengaruhi oleh dua orientasi kegiatan yang terkait dengan kegiatan sosial, yaitu adanya ValueRationality dan Instrumental-Rationality (Weber, Harmon \& Mayer: 1986:75).

1. Value-Rationality, artinya kegiatan ini secara sadar ditentukan melalui nilai-nilai individu demi kepentingan masyarakat. Formulasi nilai utama sangat mendukung terhadap dilakukannya suatu kegiatan. Hal ini akan memunculkan nilai-nilai individu secara unum yang berkembang dimasyarakat, menjadi nilai-nilai sosial yang akan mempengaruhi di dalam pelayanan. Sehingga nilai-nilai pelayanan yang diselenggarakan oleh pemerintah setidak-tidaknya mendekati kesesuaian dengan nilai-nilai masyarakat di sekitarnya.

2. Instrumental-Rationality, artinya bahwa kegiatan yang dilakukan telah memperhatikan, memperhitungkan dan 
mempertimbangkan maksud, tujuan dan konsekuensinya. Oleh karena itu pelayanan umum mengandung ukuranukuran dan nilai-nilai yang berbeda-beda di masyarakat. Nilai dan ukuran yang berbeda-beda inilah menyebabkan tuntutan masyarakat yang berbeda-beda pula, sehingga penyelenggraaan pelayanan yang dilakukan oleh pemerintah dirasakan rendah kualitasnya.

Berbagai pengertian tentang pelayanan telah diungkapkan oleh para ahli, namun pada dasarnya pelayanan merupakan aktivitas atau manfaat yang ditawarkan oleh organisasi atau perorangan kepada konsumen (customer) yang bersifat tidak berwujud dan tidak dapat dimiliki (Daviddow dan Uttal, 1989). Sementara itu yang disebut dengan konsumen atau sering disebut dengan customer, adalah masyarakat yang mendapat manfaat dari aktivitas yang dilakukan oleh organisasi atau petugas.

Pelayanan dikatakan tidak berwujud tersebut berarti bahwa pelayanan itu hanya dapat dirasakan, oleh sebab itu lebih jauh Normann (1991:14) memberikan karakteristik pelayanan sebagai berikut: Pelayanan merupakan suatu produksi yang sifatnya tidak dapat diraba, berbeda dengan barang produksi lain (barang jadi atau barang industri yang berwujud). Produksi dan konsumsi dari pelayanan tidak dapat dipisahkan secara nyata, karena pada umumnya kejadiannya bersamaan dan terjadi di tempat yang sama. Pengertian yang lebih luas dikatakan oleh Daviddow dan Uttal (1989:19), pelayanan merupakan usaha yang mempertinggi kepuasan masyarakat (whatever enhances customer satisfaction). Sementara itu pengertian pelayanan umum yang sesuai dengan Keputusan MenPAN nomor 81 tahun 1993 adalah segala bentuk pelayanan umum yang dilaksanakan oleh instasi pemerintah di pusat, di daerah, dilingkungan Badan Usaha Milik Negara atau Daerah dalam bentuk barang dan jasa, baik dalam rangka pemenuhan kebutuhan masyarakat maupun dalam rangka pelaksanaan ketentuan peraturan perundangundangan.
Pelayanan prima dalam pelayanan publik, sesuai perkembangan tuntutan pelayanan saat ini merupakan pelayanan prima atau pelayanan yang dapat memenuhi harapan masyarakat atau lebih baik dari standar dan asas-asas pelayanan publik atau masyarakat. Dalam organisasi publik ini sebenarnya telah menjadi tuntutan sejak munculnya teori negara baru (Frederickson) tentang azas keadilan. Oleh sebab itu dalam pelayanan prima pun perlu adanya standar pelayanan sebagai ukuran yang telah ditentukan untuk pembakuan pelayanan yang baik dan berkeadilan. Oleh karenanya standar pelayanan, manusia yang melaksanakan serta alat yang digunakan termasuk proses, secara terus menerus dibangun dan dievaluasi merupakan kunci utama (Hunger J. David \& Wheelen Thomas L. Diterjemahkan oleh Agung Julianto, 2001).

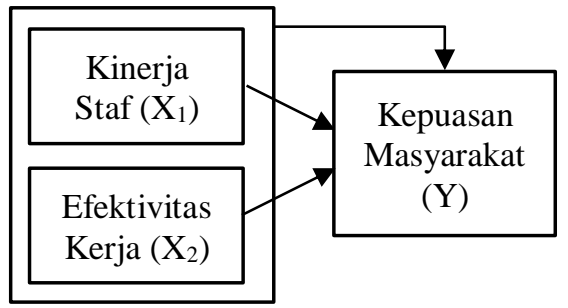

Gambar 1. Kerangka Konseptual Penelitian

Berdasarkan serangkaian teori dan penelitian terdahulu yang telah dikemukakan, maka dapat dibuat kerangka konseptual dari peneltian ini dan hipotesis penelitian. Kerangka konseptual dapat dilihat pada Gambar 1, sedangkan hipotesis penelitian adalah sebagai berikut:

H1 : Diduga kinerja staf berpengaruh signifikan terhadap kepuasan masyarakat di Desa Kramat Jegu Kecamatan Taman Kabupaten Sidoarjo.

H2 : Efektivitas kerja berpengaruh signifikan terhadap kepuasan masyarakat di Desa Kramat Jegu Kecamatan Taman Kabupaten Sidoarjo.

H3 : Diduga kinerja staf, dan efektivitas kerja secara simultan berpengaruh signifikan terhadap kepuasan masyarakat Desa Kramat Jegu Kecamatan Taman Kabupaten Sidoarjo. 


\section{Metode Penelitian}

Rancangan peneliitian menggunakan pendekatan kuantitatif deskriptif atau penelitian ekplanatori, yang menjelaskan hubungan sebab akibat antara variabel bebas dengan variabel terikat dengan tujuan untuk menguji hipotesis yang telah diajukan. Populasi dalam penelitian ini adalah warga Desa Kramat Jegu Kecamatan Taman Kabupaten Sidoarjo yang mendapatkan pelayanan pemerintah desa berjumlah 16.158 orang. Salah satu metode yang digunakan untuk menentukan jumlah sampel adalah menggunakan rumus Slovin (Sevilla et. al., 1960:182), sebagai berikut:

$$
n=\frac{N}{1+N e^{2}}
$$

Dimana :

$\mathrm{n}=$ Ukuran Sampel.

$\mathrm{N}=$ Ukuran Populasi.

$\mathrm{e}=$ Persentase kelonggaran ketidaktelitian $(5 \%)$.

Dari formulasi di atas maka dapat ditentukan jumlah sampel sebesar 390 orang atau responden, yang didapat dari:

$n=\frac{16.158}{1+16.158(0,05)^{2}}$

$n=\frac{16.158}{41,397}$

$\mathrm{n}=390,318$ (dibulatkan menjadi 390)

Teknik pengambilan sampel menggunakan incidental sampel dimana responden yang ditemui ketika sedang mengurus surat di Desa. Selanjutnya responden akan memberikan respon terhadap pertanyaan, dan melalui pilihan jawaban tertentu yang tertuang dalam kuisioner yang diadaptasikan dari instrumen yang relevan yang dikemas dalam bentuk tertutup (close ended questions atau statemens), dengan menggunakan skala likert $1-5$ (dari mulai sangat tidak memuaskan sampai dengan sangat memuaskan).
Definisi operasional dari masingmasing variabel yang digunakan dalam penelitian ini adalah:

1. Kinerja staf merupakan variabel independen (X1) yang dalam hal ini adalah hasil kerja secara kualitas dan kuantitas yang dicapai oleh seorang pegawai dalam melaksanakan tugasnya sesuai dengan tanggung jawab yang diberikan kepadanya (Mangkunegara, 2008). Sedangkan menurut Irawan (2007), kinerja adalah hasil kerja yang dapat diamati dan dapat diukur.

2. Efektivitas kerja merupakan variabel independen (X2) Menurut Richard M. Steers (1980: 1), efektivitas yang berasal dari kata efektif, yaitu suatu pekerjaan dikatakan efektif jika suatu pekerjaan dapat menghasilkan satu unit keluaran (output). Suatu pekerjaan dikatakan efektif, jika suatu pekerjaan dapat diselesaikan tepat pada waktunya sesuai dengan rencana yang telah ditetapkan.

3. Kepuasan variabel dependen (Y) merupakan tingkat perasaan setelah membandingkan kinerja atau hasil dengan harapannya. Jadi tingkat kepuasan adalah fungsi dari perbedaan antara kinerja yang dirasakan dengan harapannya (Oliver dalam Suprapto, 2001:233).

Menurut Fraenkel Jack, R. (1990) Instrumen penelitian digunakan untuk mengukur variabel yang diteliti. Instrumen yang digunakan untuk mengumpulkan data pada penelitian ini adalah observasi dan kuesioner. Analisis data dilakukan melalui analisis Regresi Linear Berganda dengan alat analisis software komputer SPSS. Serangkaian analisis yang dilakukan meliputi uji validitas untuk mengetahui sejauh mana suatu alat ukur itu dapat mengukur variabel yang akan diukur dan uji reliabilitas menggunakan koefisien Cronbach Alpha (Singgih, S, 2000) dimana Instrumen yang reliabel berarti instrumen yang digunakan berkali-kali menghasilkan data yang sama atau konsisten (Fraenkel Jack R. 1990) dan Ferdinand A. (2002) menyatakan bahwa Instrumen penelitian yang memberikan 
koefisien reabilitas lebih besar dari 0.60 dapat dikatagorikan cukup memadai untuk digunakan dalam analisis data penelitian.

\section{Hasil Penelitian dan Pembahasan}

Secara deskriptif, jumlah responden dalam penelitian ini 390 warga yang terdiri dari 200 pria dan 190 wanita. Dari 390 respoden 120 orang wiraswasta, 50 orang pegawai negeri, dan 220 orang dengan berbagai bidang pekerjaan (Pertanian, Pabrik, Musiman, Asisten Rumah Tangga). Deskripsi lengkap untuk masing-masing variabel adalah sebagai berikut:

1. Kinerja staf (X1)

Variabel kinerja staf (X1) sebagaimana dipersepsikan oleh responden menunjukkan kondisi yang cukup baik dengan skor rata-rata 3,74 dengan rentang skala 1 sampai dengan 5. Jika dihubungkan dengan alternatif 5 kriteria jawaban pada kuisioner, menunjukkan bahwa responden cukup merasakan adanya kinerja staf.

Berdasarkan data di atas variabel dari kinerja pegawai yang mendapatkan skor diatas rata rata adalah:
a. Kemampuan kerja pegawai
b. Ketepatan Penugasan
c. Mengukur kinerja
d. Realistis dalam bekerja
e. Komitmen kerja
f. Bekerja sama dengan atasan
g. Solusi permasalahan kinerja
h. Terdapat program kerja

Sedangkan pernyataan dalam kuisioner yang mendapat skor dibawah rata rata adalah:
a. Motivasi kerja pegawai
b. Sesuai keahliannya
c. Fungsi pokok pekerjaan bawahan
d. Pengawasan kerja
e. Evaluasi kinerja

2. Efektivitas kerja (X2)

Variabel variabel efektivitas kerja (X2) sebagaimana dipersepsikan oleh responden menunjukkan kondisi yang cukup baik dengan skor rata-rata 3,58 dengan rentang skala 1 sampai dengan 5 .
Data tentang penilaian responden terhadap Efektivitas kerja menunjukkan bahwa responden cukup merasakan adanya Efektivitas kerja.

Berdasarkan hasil analisis data deskriptif sub variabel efektivitas kerja yang mendapat skor relatif tinggi menurut responden adalah:

a. Memberdayakan sumber daya

b. Tepat sasaran

c. Kecakapan dalam bertugas

d. Mencapai tujuan yang ditetapkan

e. Efektivitas kerja

f. Karyawannya memiliki moral kerja yang tinggi

g. Efisiensi pemanfaatan waktu

Berdasarkan hasil analisis data deskriptif sub variabel yang mendapat skor rendah menurut penilaian responden adalah:

a. Memberdayakan sarana

b. Tanggung Jawab dalam bertugas

c. Kontribusi pencapaian tujuan organisasi

d. Pelaksanaan tujuan yang ditetapkan

e. ketepatan tanggapan organisasi pada perubahan lingkungan

f. Peran manajemen dalam koordinasi

3. Kepuasan masyarakat

Data tentang penilaian responden terhadap Kepuasan masyarakat bahwa skor ratarata 3,74. Jika dihubungkan dengan alternatif 5 kriteria jawaban pada kuesioner, menunjukkan bahwa responden cukup merasakan adanya kepuasan masyarakat.

Berdasarkan hasil analisis data deskriptif variabel kepuasan masyarakat yang mendapat skor relatif tinggi menurut responden adalah adalah:

a. Sesuai kebutuhan masyarakat

b. Dapat terpenuhi oleh pelayanan kantor pemerintah Desa.

c. Masyarakat menerima pelayanan yang efektif

d. Pelayanan kantor pemerintah Desa menimbulkan rasa loyalitas masyarakat terhadap pemerintah Desa

e. Masyarakat merasa mendapatkan jaminan kepuasan 
f. Pemerintah Desa menjalin komunikasi yang baik dengan masyarakat

g. Masyarakat menjalain komunikasi yang baik dengan pemerintah Desa.

h. Masyarakat memliki sifat simpati pada pemerintah Desa.

Berdasarkan hasil analisis data deskriptif variabel yang mendapat skor rendah menurut penilaian responden adalah:

a. Sesuai Harapan masyarakat

b. Masyarakat menerima pelayanan yang efisien

c. Masyarakat merasa mendapatkan jaminan kemudahan

d. Pemerintah Desa memilki sikap empati pada masyarakat,

e. Pelayanan pemerintah Desa menimbulkan kejujuran antara yang melayani dan masyarakat yang dilayani

Dalam melakukan Uji hipotesis dalam penelitian ini dipaparkan data hasil uji hipotesis dari masing masing hipotesis sbb:

1. Pengaruh kinerja staf terhadap kepuasan masyarakat.

Berdasarkan hasil analisis data tersebut di atas dapat diketahui bahwa nilai $\mathrm{R}$ Square sebesar 0,234. Hal ini berarti besarnya pengaruh kinerja staf pemerintahan Desa terhadap variabel dependen yakni kepuasan masyarakat sebesar 23,4\%. Sedangkan kepuasan masyarakat pemerintahan Desa yang tidak bisa dijelaskan atau dipengaruhi oleh kinerja staf sebesar 76,6 \%. Ini artinya, 76,6\% kinerja staf dijelaskan oleh faktor-faktor lain yang tidak ikut diteliti pada penelitian ini. Faktor-faktor ini bisa bermacammacam, seperti hal yang berkaitan dengan insentif, lingkungan fisik, lingkungan non fisik dan hal-hal lain yang jika dikaji secara teori memiliki kemampuan tersendiri untuk mempengaruhi kepuasan masyarakat desa.

2. Pengaruh efektivitas kerja terhadap Kepuasan masyarakat.
Berdasarkan hasil analisis data tersebut di atas dapat diketahui bahwa nilai Square sebesar 0,426. Hal ini berarti besarnya pengaruh Efektivitas kerja terhadap variabel dependen yakni Kepuasan masyarakat sebesar 42,6\%. Sedangkan Kepuasan masyarakat yang tidak bisa dijelaskan atau dipengaruhi oleh Efektivitas kerja staf pemerintahan Desa Kramat Jegu Kecamatan Taman Kabupaten Sidoarjo sebesar 57,4\%.

3. Pengaruh kinerja dan efektivitas kerja terhadap Kepuasan masyarakat secara simultan

Berdasarkan hasil analisis pada Tabel 1 dapat diketahui bahwa nilai Square sebesar 0,442. Hal ini berarti besarnya pengaruh kinerja staf dan efektivitas kerja pemerintahan Desa variabel dependen yakni kepuasan masyarakat sebesar 44,2 $\%$. Sedangkan kepuasan masyarakat Desa Kramat Jegu Kabupaten Sidoarjo yang tidak bisa dijelaskan atau dipengaruhi oleh kinerja staf dan efektivitas kerja pemerintahan Desa Kramat Jegu secara simultan sebesar 55,8\%.

Berdasarkan hasil analisis pada Tabel 2 dapat diketahui bahwa nilai signifikan sebesar 0,00, yakni lebih kecil dari 0,05. hal ini berarti kinerja staf dan efektivitas kerja secara simultan berpengaruh positif terhadap variabel dependen yakni kepuasan masyarakat Desa Kramat Jegu Kecamatan Taman Kabupaten Sidoarjo.

Berdasarkan hasil analisis dapat diketahui bahwa kinerja staf berpengaruh positif terhadap variabel dependen yakni kepuasan masyarakat pemerintahan Desa Kramat Jegu Kabupaten Sidoarjo. Besarnya pengaruh kinerja staf pemerintahan Desa terhadap variabel dependen yakni kepuasan masyarakat sebesar 23,4 \%. Sedangkan kepuasan masyarakat Kabupaten Sidoarjo yang pemerintahan Desa Kramat Jegu tidak bisa dijelaskan atau dipengaruhi oleh kinerja staf sebesar 76,6\%. 
Tabel 1. ANOVA

\begin{tabular}{ccccc}
\hline Model & $\mathrm{R}$ & R Square & Adjusted R Square & Std. Error of the Estimate \\
\hline 1 &, $665^{\text {a }}$ &, 442 &, 439 &, 78459 \\
\hline \multicolumn{2}{l}{ a. Predictors: (Constant), Efektivitas Kerja, Kinerja Staf } & \\
\hline
\end{tabular}

Tabel 2. Koefisien Regresi

\begin{tabular}{llrrrrr}
\hline Model & & Sum of Squares & df & $\begin{array}{r}\text { Mean } \\
\text { Square }\end{array}$ & F & Sig. \\
\hline 1 & Regression & 163,458 & 2 & 81,729 & 132,766 &, $000^{\text {a }}$ \\
\hline & Residual & 206,222 & 335 &, 616 & & \\
\hline Total & 369,679 & 337 & & & \\
\hline
\end{tabular}

Pelayanan yang dilakukan oleh pemerintah sering disebut dengan pelayanan umum, yang dimaksud dengan pelayanan umum adalah sesuatu yang disediakan baik oleh organisasi pemerintah maupun swasta, kerena masyarakat umumnya tidak dapat memenuhi sendiri kebutuhan-nya kecuali melalui kolektif. Pemenuhan kebutuhan dilakukan untuk seluruh masyarakat guna kesejahteraan sosial. (Londsdale: 1994). Sementara itu pengertian pelayanan umum yang sesuai dengan Keputusan MenPAN nomor 81 tahun 1993 adalah segala bentuk pelayanan umum yang dilaksanakan oleh instasi pemerintah di pusat, di daerah, dilingkungan Badan Usaha Milik Negara. Pelayanan Prima Dalam Pelayanan Publik Perkembangan tuntutan pelayanan saat ini adalah pelayanan prima atau pelayanan yang dapat memenuhi harapan masyarakat atau lebih baik dari standar dan asas-asas pelayanan publik atau pelanggan. Dalam organisasi publik hal ini sebenarnya telah menjadi tuntutan sejak munculnya teori negara baru (Frederickson) tentang azas keadilan. Oleh sebab itu dalam pelayanan primapun standar pelayanan digunakan sebagai ukuran yang telah ditentukan untuk pembakuan pelayanan yang baik dan berkeadilan. Bila seluruh pelayanan telah memiliki standar maka dapat mempermudah dalam memberikan pelayanan yang lebih baik, sehingga secara kontinyu dapat disebut prima. Pelayanan prima dapat digunakan dalam segala bentuk pelayanan dan dalam membangunnya juga dapat dilakukan dengan berbagai strategi. Prinsip yang utama dalam pelayanan prima adalah memberikan kepuasan terhadap pelanggan, namun tidak berarti bahwa pelayanan harus mengikuti keinginan pelanggan belaka. Namun juga harus mempertimbangkan adanya keseimbangan antara kemampuan dan tuntutan pelanggan. Oleh karenanya dalam standar pelayanan, manusia yang melaksanakan serta alat yang digunakan termasuk proses, secara terus menerus dibangun dan merupakan kunci utama (HungerbJ. David \& Wheelen Thomas L. Diterjemahkan oleh Agung Julianto, 2001).

Actuating dan controlling merupakan fungsi dari manajemen lainnya di samping planning dan organizing. Actuating adalah fungsi manajemen yang erat hubungannya dengan unsur manusia.Yang penting diketahui dari fungsi actuating ini adalah pemberian motivasi kepada orang-orang yang merupakan anggota organisasi. Di samping itu dalam kegiatan actuating, seorang pimpinan harus dapat membuat sinkronisasi antara tujuan organisasi dengan tujuan individu para anggota organisasi. Dengan demikian, maka pimpinan harus mengetahui dan memenuhi keinginan pekerja secara individual di samping tujuan organisasi (Bowman, Ann O’M. \& Kearney, Richard C, 2000).

Untuk menghasilkan kualitas kerja yang optimal, salah satu indikatornya akan dipengaruhi oleh sikap dan perilaku manajemen eksekutif. Sepak terjang manajemen eksekutif aktivitasnya dapat berpengaruh dalam proses implementasi kebijakan, maka manajemen eksekutif harus mampu menyesuaikan diri dengan tuntutan kebutuhan organisasi dan lingkungan yang 
senantiasa selalu berubah. Manajemen eksekutif dalam melaksanakan aktivitas dan fungsinya senantiasa berkoordinasi dengan lainnya, tidak berdiri sendiri apalagi sampai lepas satu sama lainnya, akan tetapi saling berkaitan (Mochtar, Hilmy, DR. MS, 2004).

Merencanakan, mengorganisasikan, memimpin, dan mengendalikan adalah tindakan simultan dan saling berhubungan, yang akan membawa pada peningkatan hasil kinerja. Intensitas penerapan sikap dan perilaku yang bermutu merupakan filosofi untuk mengubah paradigma manajemen eksekutif lama yaitu dari sikap dan perilaku yang dilayani, menjadi manajemen eksekutif yang melayani publik secara bermutu (prima). Terlihat bahwa faktor manusia menjadi kunci utama. Ini sejalan dengan model pembangunan yang menggunakan strategi People Centered Development (PCD) yang memandang publik sebagai pusat pembangunan, di mana pemerintah dan sistem manajemennya berperan sebagai fasilitator (Mochtar, Hilmy. 2004).

Manajemen menggerakkan segenap sumber daya organisasi sedemikian rupa secara harmonis dalam mencapai tujuan organisasi. Karena itu manajemen mengisyaratkan adanya unsur kepemimpinan, pengambilan keputusan, hubungan antar manusia, dan manusianya itu sendiri. Pendapat para ahli mengenai fungsifungsi manajemen berbeda-beda, namun daribeberapa pendapat tersebut, dapat dipahami bahwa sesungguhnya manajemen itu terdiri dari proses perencanaan, pengorganisasian, penggerakan, dan pengawasan (sebagaimana yang dikemukakan oleh Terry Wahjosumidjo, 2004).

Sedangkan fungsi pengawasan merupakan fungsi manajemen yang di dalamnya terkandung kegiatan perbaikan dan penyempurnaan sehingga pekerjaan atau kegiatan sesuai dengan rencana atau tujuan yang telah ditetapkan. Penting diketahui bahwa pengawasan sangat erat hubungannya dengan fungsi perencanaan yaitu dengan adanya pengawasan maka kegiatan yang telah mendapat perbaikan dan penyempurnaan ini akan menjadi feedback bagi perencanaan berikutnya.
Berdasarkan hasil analisis data tersebut di atas dapat diketahui bahwa efektivitas kerja berpengaruh positif terhadap variabel dependen yakni Kepuasan masyarakat Desa Kramat Jegu Kecamatan Taman Kabupaten Sidoarjo. Besarnya pengaruh efektivitas kerja terhadap variabel dependen yakni Kepuasan masyarakat sebesar 42,6\%. Sedangkan Kepuasan masyarakat yang tidak bisa dijelaskan atau dipengaruhi oleh Efektivitas kerja staf pemerintahan Desa Kramat Jegu Kabupaten Sidoarjo sebesar 57,4\%.

Standar pelayanan yang ditetapkan hendaknya realistis, karena merupakan jaminan bahwa janji atau komitmen yang dibuat dapat dipenuhi, jelas dan mudah dimengerti oleh para pemberi dan penerima pelayanan.

Untuk memenuhi kebutuhan informasi pelayanan kepada masyarakat, setiap unit pelayanan instansi pemerintah wajib mempublikasikan prosedur, persyaratan, biaya, waktu, standar, akta atau janji, motto pelayanan, lokasi serta pejabat/petugas yang berwenang dan bertanggung jawab sebagaimana telah diuraikan di atas.

Publikasi dan atau sosialisasi tersebut di atas dilakukan melalui, media cetak (brosur, leaflet, booklet), media elektronik (website, home-page, situs internet, radio, televisi), media gambar dan atau penyuluhan secara langsung kepada masyarakat (Smith, B.C., 1988.).

Berdasarkan hasil analisis data tersebut di atas dapat diketahui bahwa kinerja staf dan efektivitas kerja secara simultan berpengaruh positif terhadap variabel dependen yakni kepuasan masyarakat di Desa Kramat Jegu Kecamatan Taman Kabupaten Sidoarjo. Besarnya pengaruh kinerja staf dan efektivitas kerja pemerintahan Desa secara simultan terhadap variabel dependen yakni kepuasan masyarakat sebesar 44,20\%. Sedangkan kepuasan masyarakat Desa Kramat Jegu Kabupaten Sidoarjo yang tidak bisa dijelaskan atau dipengaruhi oleh kinerja staf dan efektivitas kerja pemerintahan Desa Kramat Jegu secara simultan sebesar 55,80\%. Kualitas dalam penyelenggaraan pelayanan dewasa ini dirasakan tuntutan sangat meningkat. Masyarakat pada umumnya tidak dapat lagi dipenuhi 
kebutuhannya atas dasar standar pemerintah semata, melainkan telah dituntut adanya

kualitas layanan yang ditentukan oleh kebutuhan masyarakatnya sendiri. Kebutuhan tersebut ditujukan baik terhadap barang privat maupun terhadap barang publik (Lean, Iain Mc., 1999).

Berbagai pengertian tentang pelayanan telah diungkapkan oleh para ahli, namun pada dasarnya pelayanan merupakan aktivitas atau manfaat yang ditawarkan oleh organisasi atau perorangan kepada konsumen (customer) yang bersifat tidak berwujud dan tidak dapat dimiliki. (Daviddow dan Uttal, 1989). Sementara itu yang disebut dengan konsumen atau sering disebut dengan customer, adalah masyarakat yang mendapat manfaat dari aktivitas yang dilakukan oleh organisasi atau petugas.

Kepuasan pelanggan adalah suatu keadaan dimana keinginan, harapan dan kebutuhan pelanggan dipenuhi. Suatu pelayanan dinilai memuaskan bila pelayanan tersebut dapat memenuhi kebutuhan dan harapan pelanggan. Pengukuran kepuasan pelanggan merupakan elemen penting dalam menyediakan pelayanan yang lebih baik, lebih efisien dan lebih efektif. Apabila pelanggan merasa tidak puas terhadap suatu pelayanan yang disediakan, maka pelayanan tersebut dapat dipastikan tidak efektif dan tidak efisien.

Menurut Reichheld dan Sasser (1990), loyalitas pelanggan memiliki korelasi yang positif dengan performa bisnis (Beerli dkk, 2004). Menurut Castro dan Armario (1999), loyalitas pelanggan tidak hanya meningkatkan nilai dalam bisnis, tetapi juga dapat menarik pelanggan baru (Beerli dkk, 2004). Pada jangka pendek, memperbaiki loyalitas pelanggan akan membawa profit pada penjualan. Profit merupakan motif utama konsistensi bisnis, karena dengan keuntungan maka roda perputaran bisnis dari variasi produk dan jasa yang ditawarkan maupun perluasan pasar yang dilayani (Soeling, 2007).

Pengukuran kepuasan pelanggan merupakan elemen penting dalam menyediakan pelayanan yang lebih baik, lebih efisien dan lebih efektif. Apabila pelanggan merasa tidak puas terhadap suatu pelayanan yang disediakan, maka pelayanan tersebut dapat dipastikan tidak efektif dan tidak efisien. Hal ini terutama sangat penting bagi pelayanan publik. Pada kondisi persaingan sempurna, dimana pelanggan mampu untuk memilih di antara beberapa alternatif pelayanan dan memiliki informasi yang memadai, kepuasan pelanggan merupakan satu determinan kunci dari tingkat permintaan pelayanan dan fungsi atau operasionalisasi pemasok Atmaja, H.S. 2003.

Berdasarkan SK Men PAN Nomor 26 Tahun 2004, negara kita mencoba menerapkan prinsip-prinsip keterbukaan (transparansi) dalam penyelenggaraan pelayanan publik. Transparansi berarti warga dapat mengetahui bagaimana pelaksanaan tugas dan kegiatan penyelenggaraan pelayanan publik, sejak dari proses kebijakan, perencanaan, pelaksanaan dan pengawasan atau pengendalian. Manajemen dan penyelenggaraan pelayanan publik meliputi kebijakan, perencanaan, pelaksanaan dan pengawasan atau pengendalian oleh masyarakat. Seluruh kegiatan tersebut harus dapat diinformasikan dan mudah diakses oleh masyarakat. Prosedur pelayanan publik harus sederhana, tidak berbelit-belit.

\section{Kesimpulan}

Atas dasar hasil penelitian, maka dapat ditarik beberapa kesimpulan sebagai berikut:

1. Kinerja staf berpengaruh positif terhadap kepuasan masyarakat pemerintahan Desa Kramat Jegu Kecamatan Taman Kabupaten Sidoarjo

2. Efektivitas kerja berpengaruh positif terhadap Kepuasan masyarakat atau publik Desa Kramat Jegu Kecamatan Taman Kabupaten Sidoarjo.

3. Kinerja staf dan efektivitas kerja secara simultan berpengaruh terhadap variabel dependen yakni kepuasan masyarakat atau publik Desa Kramat Jegu Kecamatan Taman Kabupaten Sidoarjo.

Berdasarkan kesimpulan tersebut di atas, maka peneliti merekomendasikan saran sebagai berikut:

1. Perangkat Desa hendaknya tetap mempertahankan kualitas kinerja dalam 
melaksanakan program layanan masyarakat atau publik.

2. Kepala Desa perlu mempertahankan kualitas manajemen pemerintahan Desa yang sudah berjalan saat ini dengan tidak mengabaikan untuk meningkatkan kualitas SDM dilingkungannya melalui implementasi kebijakan dalam rangka pelayanan pada masyarakat atau publik serta selalu mengikuti pengembangan SDM yang diselenggarakan Pemerintah.

3. Bagi peneliti selanjutnya perlu mengkaji tentang kebijakan yang menyangkut komitmen organisasi dan penelitian tidak hanya satu Desa dalam wilayah Kecamatan tersebut karena setiap Desa memiliki karakteristik yang berbeda.

\section{DAFTAR PUSTAKA}

Abdurahman, Maman, Muhidin, Sambas \& Somantri, Ating. 2012. Dasar-Dasar Metode Statistika Untuk Penelitian. CV. Pustaka Setia, Bandung.

Abrahamsen, Rita. 2004 (terj). Sudut Gelap Kemajuan Relasi Kuasa Dalam Wacana Pembangunan. Lafald pustaka, Yogyakarta.

Arikunto, Suharsimi. 2002. Metodologi Penelitian. Penerbit PT. Rineka Cipta, Jakarta.

Amstrong, Michael, 1999. Manajemen Sumber Daya Manusia. (Terjemahan Sofyan dan Haryanto). PT. Elex Media Komputindo, Jakarta.

Atmaja, H.S. 2003. Pengaruh Kualitas Jasa Terhadap Kepuasan Pelanggan Dalam Membangun Loyalitas Pelanggan (Studi Kasus Pelanggan Multimedia Akses PT Telkom). Tesis. Fakultas Ekonomi Universitas Indonesia, Jakarta.

Azwar, S, 2009, Sikap Manusia, Teori dan Pengukurannya, Pustaka Pelajar. Jakarta.

Beerli dkk. 2004. Business Service Quality and The Mediating Role of Customer Satisfaction. European Journal of Marketing, 36.

Beerli dkk. 2004. Mediating, Interactive, and Non Linear Effects in Service Quality and Satisfaction with Services
Research. Canadian Journal of Administrative Sciences, 19.

Bowman, Ann O’M. \& Kearney, Richard C. 2000. The Essentials State And Local Government, Buruecracy And Democracy A Political Dilemma, Routledge \& Kegan Paul, London Creech, Bill (2006), Total Quality Management, The Second Edition, Cambridge Publishing, Cambridge.

Covey, Stephen R. 1997, The 7 Habits of Highly Effective People, Alih Bahasa: Budijanto, Bina Rupa Aksara, Jakarta.

Davidow, William H \& Bro Uttal. 1989. Total Customer Service The Ultimate Weapon. The Free Press, New York.

Dessler, Alexander. 2005. Performance Measurement, First Edition Prentice Hall, New Jersey.

Dick dan Basu. 1994. A National Customer Satisfaction Barometer: The Swedish Experience. Journal of Marketing, 56.

Edwards, H. Cliford, et.al. 1988. Planning, Teaching, and Evaluating: A Competency Approach. Nelson-Hall, Chicago.

Elu, Castro dan Armario 1999. The Behavioral Consequences of Service Quality. Journal of Marketing, 60.

Fardhani, Harentama. Analisis Faktor-faktor yang Mempengaruhi Kepuasan Masyarakat pada Pelayanan Badan Pelayanan Perijinan Terpadu Kota Semarang. Fakultas Ekonomi Universitas Diponegoro, Semarang.

Ferdinand, Augusty. 2002. Structural Equation Modelling dalam Penelitian Manajemen. Fakultas Ekonomi Universitas Diponegoro, Semarang.

Fianstein and Norman, 1991. City Planning and Political Value, Journal Urban Affairs Quarterly, Vol. 2, No.3.

Fraenkel, Jack R. 1980. Helping students think value strategies for teaching social studies. Prentice-Hall, New Jersey.

Fred Fiedler. 2006. Human Resources Management in the Global Era, First Edition, McGraw Hill, New York.

Frederickson, H. George \& Jocelyn M. Johnston (Eds.). 1999. Public Management Reform and Innovation: 
Research, Theory, and Application. Alabama, London.

Gaffar, Afan. 2002. Politik Indonesia Transisi Menuju Demokrasi. Pustaka Pelajar, Yogyakarta.

Gaffar, Maruli. 2007. Manajemen Sumber Daya Manusia, Edisi Kedua, Cetakan Kedua, Penerbit Bina Aksara, Jakarta.

Gasperz, Vincent. 1997. Manajemen Kualitas (dalam Industri Jasa). Cetakan Pertama.

PT. Gramedia Pustaka utama, Jakarta

Gazpers, Vincent. 1997. Manajemen Bisnis Total Dalam Era Globalisasi, PT. Gramedia Pustaka utama, Jakarta.

Gibson, Meil. 2003. Organizational Behaviour, The Student Edition, The Boston Publishing, Boston.

Gilmer, Johny 2006. The Changing Models, Third Edition, Cambridge Publishing, Cambridge.

Ginting, 2008. Metode Penelitian kuantitatif, Edisi Kedua, Penerbit Grafiti Press, Jakarta.

Gipson, James L, Ivanceiulech, John M, James H Donely Ir. 1997. Organizations, Terjemahan, Edisi 8, Jakarta: Bina Rupa Aksara.

Hamdani, A. 2006. Pengetahuan:Aset Organisasi, Cetakan Pertama, Edisi Pertama, Penerbit Grafiti, Bandung.

Harold Kontz, Cyrill O. Donnel dan Heinz Weichrich 2004. The Effective Leadership, The Boston University Press, Boston.

Held, David. 2004 (terj). Demokrasi Dan Tatanan Global Dari Negara Modern Hingga Pemerintahan Kosmopolitan, Pustaka Pelajar, Yogyakarta.

Herzberg Frederick. 2000. Organizational Behavior. Tenth Edition. Prentice Hall, New Jersey.

Hipni, Rohman. 2011, Definisi atau pengertian Efektivitas Kerja, [online], (http://hipni.blogspot.com/2011/07/defi nisipengertian-efektivitas-kerja.html)

Houghton Mifflin Company, Boston Dhal, Robert. 2001. Perihal Demokrasi Menjelajahi Teori Dan Praktek Demokrasi Secara Singkat. Yayasan Obor Indonesia, Jakarta.
Irawan, Bambang, (2007), Manajemen Kinerja, Edisi Kedua, Cetaka Pertama, Penerbit Grafiti, Bandung.

Keban, Yeremias T., 2004. Enam Dimensi Strategis Adminsitrasi Publik Konsep, Teori Dan Isu, Gaya Media, Yogyakarta.

Kerlinger. (1990). Asas-asas Penelitian Behavior (Alih Bahasa). IKIP, Semarang.

Londsdale: 1994). . Health Education in the Elementary School. W.B. Soundera Company, Toronto.

Lunnenburg, Jeremy (2005) Problem Solving Strategy, First Edition, UN Press, Washington.

Luthans, F. 2005. Organizational Behavior. McGraw-hill, New York.

Malhotra, N. K. 1996. Marketing Research: An Applied Orientation. 2nd Edition. Prentice Hall Inc, New Jersey.

Mangkunegara, Romo. 2008. Manajemen Personalia, Edisi Kedua, Penerbit Andi Offset, Yogyakarta.

Mangkunegara, Anwar Prabu. 2002. Manajemen Sumber Daya Manusia. Remaja Rosdakarya. Bandung

Mathis, R.L. \& J.H. Jackson. 2006. Human Resource Management: Manajemen Sumber Daya Manusia. Terjemahan Dian Angelia. Salemba Empat, Jakarta.

Mitchell, Share. 2008. Social Sciences Theory, Third Edition, Mc GrawHill Publishing, Philadelpia

Mochtar, Hilmy, DR. MS., 2004. Politik Lokal dan pembangunan, Pustaka Pelajar, Yogyakarta

Mockler, R. (1972). The Management Control Process. Englewood Cliffs, Prentice-Hall, New Jersey

Nadler, David.A, and Nadler, Mark B. 1998. Champion of Change: How CEOs and Their Companies Are Mastering the Skills of Radical Change, Jossey-Bass Publishers, San Franncisco, USA.

Nimran, Umar. 2009. Perilaku Organisasi Modern, Cetakan Kedua, Penerbit Bayumedia Publishing, Malang.

Nurlaila, 2010. Manajemen Sumber Daya Manusia I. Penerbit LepKhair. 
Peraturan, No. 05/PB/2001, Diskriminasi Dalam Pemberian Pelayanan Publik. PSKK UGM, Yogyakarta.

Prawirosentono, Suryadi. 1999. Kebijakan Kinerja Karyawan. BPFE, Yogyakarta.

Petras, James \& Veltmeyer, Henry. 2002. Imperialisme Abad 21, Kreasi Wacana, Yogyakarta

Philpott, Simon. 2003 (terj). Meruntuhkan Indonesia Politik Postkolonial Dan Otoritarianisme. LkiS, Yogyakarta.

Porter, Michael, E. 1985. "Competitive Advantage: Creating and Substaining superior Performance". Free Press, New York.

PSKK UGM, 2001. Policy Brief, No. 01/PB/2001, Kinerja Pelayanan Publik ,Yogyakarta.

R, Bintarto. 1977. Filsafat Administrasi. PT Gunung Agung, Jakarta.

Robbins dan Judge, 2008. Behaviour Theory, The Seventh Edition, Edisi Bahasa Indonesia, Jilid I dan II, PT Indeks Kelompok Gramedia, Jakarta.

Roscoe, J.T. 1975. Fundamental Research Statistic for The Behavior Sciencess. (2nd, ed), Holt, Rinehart and Winston. New York.

Rosyada, Dede. 2003. Demokrasi, Hak Asasi Manusia dan Masyarakat Ma-dani, Prenada Media dan TIM ICCE UIN Jakarta, Jakarta.

Robbins, Stephen P., 2006. Perilaku Organisasi, PT Indeks Kelompok Gramedia, Jakarta.

Rivai, Vethzal \& Basri. 2005. Peformance Appraisal: Sistem yang tepat untuk Menilai Kinerja Karyawan dan Meningkatkan Daya Saing Perusahaan. PT. Raja Grafindo Persada, Jakarta.

Robbins, Stephen P., 1996. Perilaku Organisasi. Jilid II, Alih Bahasa Hadayana Pujaatmaka, Prenhalindo, Jakarta.

Russell, James D. 1984. Modular Instruction: A Guide to Design, Selection, Utilization and Evaluation of Modular Materials. Burgess Publishing Company, Minneapolis.

Sekaran .2006. Metode Penelitian Survei, Edisi Pertama, Cetakan Ketujuh, Penerbit LP3ES, Jakarta.
Sergiovanni, J.T \& Starrat, J. R. 1983. Supervisi Human Perspectives (1st ed). Mc. Graw-Hill, New York

Sherman \& George, 2007. The Motivation Theories, First Edition, Cambridge University Press, London.

Sherman \& George, 2007. Performance Management, Second Edition, Longman, Inc, Philadelpia.

Sherman \& George, 2009, Total Personel Management, Second Edition, The Boston Publishing, Boston.

Siagian, Albert. 2008, Perilaku Organisasi Sektor Bisnis, Cetakan Pertama, Edisi Pertama, PT. PT Gunung Agung, Jakarta.

Siagian, S.P. 1998. Manajemen Strategis. Cetakan Kedua. Bumi Aksara, Jakarta.

Sondang P. (1981). Filsafat Administrasi. PT Gunung Agung, Jakarta.

Singarimbun dan Effendi. 1995. Metode Penelitian Survei. LP3ES, Jakarta.

Situmorang, Tumpal. 2009. Manajemen Personalia Modern, Edisi kedua, Cetakan Pertama, Penerbit Citra Mentari Group, Malang.

Smith, B.C., 1988. Buruecracy and Political Power, ST. Martin's Press, New York.

Soeling, Pantius D. 2007, Pertumbuhan Bisnis dan Tanggung jawab sosial perusahaan. Jurnal Ilmu Administrasi dan Organisasi, Bisnis \& Birokrasi, Vol. 15, No 1 (Januari).

Stephen P. Robbins, 1996. Perilaku Organisasi, Konsep, Kontroversi dan Aplikasi. Alih Bahasa: Hadyana Pujaatmaka. Edisi Keenam. Penerbit PT.Bhuana Ilmu Populer, Jakarta.

Steers, M. Richard. 1985. Efektifitas Organisasi. PT Erlangga, Jakarta.

Sugiono, (2005), Statistik Untuk Penelitian dan Aplikasinya dengan SPSS 19.0 For Windows, Alfabeta, Bandung.

Sugiyono. 1998. Metode Penelitian Administrasi. Alfabeta, Bandung.

Suit, Y dan Almasdi. 2000. Aspek Mental Manajemen Sumber Daya Manusia, Ghalia Indonesia, Jakarta

Wahjosumidjo, 2004. Kepemimpinan dan Motivasi. Ghalia Indonesia, Jakarta

Weber, Harmon \& Mayer. 1986. Planning, Teaching, and Evaluating: A 
Competency Approach. Nelson-Hall, Wheelen Thomas L., dan David Hunger J. Chicago. 2000.“ Strategic Management and

Weisbord. 2008. Social Sciences Theory. Bussiness Policy," Fourth Edition, The Third Edition, Mc Graw Hill Publishing, Philadelpia. Addison Wesley Publishing Company, New York.

Weisbord, John. 2008. Human Resouces Management, Third Edition, Mc Graw Hill, Philadelpia.

Winarno, Budi. 2004. Globalisasi Wujud Imperialisme Baru Peran Negara Dalam Pembangunan, Tajidu Press, Yogyakarta. 